\title{
Biota of lichens on the Zadroże Dune and its immediate surroundings
}

\author{
Edyta Adamska
}

\author{
Department of Plant Taxonomy and Geography, \\ Institute of Ecology and Environment Protection, Faculty of Biology and Earth Sciences, \\ Nicolaus Copernicus University, \\ Gagarina 9, 87-100 Toruń, Poland, e-mail: adamska@umk.pl
}

\begin{abstract}
The present paper aims at describing the biota of lichens of the Zadroże Dune and its adjacent area in Torun. The research on lichens was conducted during the years 2005-2006. The data on lichens come from my own research and literature. Altogether, the occurrence of 82 lichen taxa was recorded in the investigated area, including 74 species recorded during my own research. Due to the availability of habitats and substrata, terricolous species dominate here, mainly from the genus Cladonia and Cetraria. Particularly noteworthy are rare, endangered and protected species from this area e.g. Peltigera canina, Polyblastia agraria, Rinodina conradii and Stereocaulon condensatum.
\end{abstract}

Key words: lichens, dry sand grasslands, eutrophication, Torun.

\section{Introduction}

Within the territory of Torun, the most characteristic elements of the landscape relief are the ice-marginal valleys and river valleys with the preserved system of river terraces and edges in between. Extensive dune areas spread out over all terraces, except the floodplain. In the valley of Torun, the biggest dune complex occurs within the early post-glacial relief of the Polish Lowland, and within the city of Torun its significant fragment called the field of Torun, Aleksandrów and Gniewkowo. Dunes within the city can be described as parabolic, straight linear, irregularly undulated with more or less smooth surface (Niewiarowski \& Weckwerth 2006).

Together with spatial development of Toruń, some permanent anthropogenic relief transformations have taken place. Some of the dune areas have been completely destroyed due to the expansion of residential and industrial areas, sport facilities and communication routes. At present, most of the sandy dune fields are covered with pine and mixed forests.

Among the dune areas, the Zadroże Dune is particularly noteworthy together with the adjacent areas, especially near the street Poznańska due to the biota of lichens inhabiting those areas (Anikiejówna \& Gorska 1949).

Scattered dune grasslands of the following communities occur there: Spergulo-Corynephoretum, Festuco-Koelerietum glaucae and Caricetum arenariae, and farther towards the Zadroże Dune the contribution of Calluna vulgaris is more pronounced, particularly in places where forest was cut down. Over a relatively large area of this territory, despite the neighbourhood of roads, residential and industrial development, well preserved communities of inland dunes occur with numerous lichen species (Ceynowa-Giełdon et. al. 2004). 


\section{Materials and methods}

Lichenological studies covered the Zadroże Dune situated in the commune of Wielka Nieszawka and the adjacent eastern area situated within the administrative boundaries of the city of Torun. In accordance with the ATPOL system of squares, modified for lichenological objectives (Cieśliński \& Fałtynowicz 1993), the adjacent south-western end of Torun, presented in Figure 1, is included within the squares of $10 \times 10 \mathrm{~km}, \mathrm{Cc}-49$ and $\mathrm{Cd}-40$, additionally divided into fields of $1 \times 1 \mathrm{~km}$.

According to cartographic, floristic and phytosociological data, in the mid-20th century the Zadroże Dune was covered with heaths and psammophilous grasslands. According to the information acquired from the Forest Division of Cierpiszewo, the dune has been gradually afforested since 1950. Nowadays, it is covered with 30-60-year old pine forest, where the undergrowth and the herb layer occur only here and there. The lists of terrestrial lichens occurring at two research sites before the afforestation of the dune, published by Anikiejówna and Gorska (1949), were used for comparisons with the species composition recorded during my field studies in the research area situated within the boundaries of Torun, marked in Figure 1. This fragment of the city has been deforested to this day. Today, most of the research area is covered with the same plant communities as the Zadroże Dune before it was afforested. During the 2nd World War, part of this area was converted to the prisoner-of-war camp (Stalag XX), first with French and British prisoners and from 1941 - with Russian ones. This area was described as Soviet Heide (Tyszkiewicz 1976). At the turn of the 1960s and the 1970s in the eastern part of this area, production floors and an administrative building of a poultry plant were built. At the beginning of the 1980s at the back of this plant, allotment gardens were established. At the beginning of the 21 st century, the Torun ring road was constructed through the south-western part of this area, next to which warehouses with building materials and car showrooms were created.

Nowadays, places that are not covered by forest, cultivated vegetation or buildings, are covered by heath vegetation, psammophilous grasslands, patches of mosses, particularly Polytrichum piliferum, and terrestrial lichens. The species composition of terrestrial lichens occurring there at the turn of the 20th and 21st centuries was determined by Ceynowa-Giełdon (1993) and Ceynowa-Giełdon et al. (2004). The detailed description of physiographic conditions, vegetation and the history of the Zadroże Dune, as well as the research area located in the territory of Torun are presented by other articles included in the 12th Issue of Ecological Questions.

In the Table 1 with species lists of lichens, two research sites on the Zadroże Dune, the lichen species of which were studied by Anikiejówna and Górska (1949), were denoted with symbols A. The list of lichens occurring in the 1990s and at the beginning of the 21 st century in the area located near Torun, published by Ceynowa-Giełdon (1993) and Ceynowa-Giełdon et al. (2004), was denoted by the symbol B and C, respectively. Biota of lichens, which I determined in the area situated within the city of Torun (Fig. 1) concern the state of 2005 and 2006.

Collection of lichens within the said area was done from all possible substrata of their occurrence, with particular consideration to terricolous lichens (epigeic). Moreover, substrata like bark of trees (Acer platanoides, Betula pendula, Pinus sylvestris, Populus ssp.) were analysed; inventory and collection of lichens were also conducted from wood, acid and artificial calcareous rock substrata, as well as other substrata of anthropogenic origin (leather, slag, thalli of other lichens).

The identification keys by Purvis et. al. (1992), Wirth (1995) and other monographs were used to determine the collected lichens. Also the method of thin-layer chromatography (TLC) was applied according to Orange et al. (2001) for the following genera: Cladonia and Lepraria, as well as for the species - Scoliciosporum sarothamni and Lecanora expallens. Specimens of Cladonia from the group chlorophaea not confirmed chromatographically were defined as Cladonia chlorophaea s. 1.

The names of lichens are given after Diederich et al. (2009) and Santesson et al. (2004). The collected herbarium material has been deposited at the Herbarium of the Institute of Ecology and Environment Protection Nicolaus Copernicus University in Toruń (TRN).

\section{Results}

In total, 82 lichen taxa were recorded in the territory of the Zadroże Dune and its immediate surroundings. Data on biota of lichenized fungi come from both literature and my own research (Tab. 1).

At present, the presence of previously recorded taxa, such as: Cetraria ericetorum, Cladonia cariosa, C. chlorophaea, C. furcata subsp. subrangiformis, Placynthiella oligotropha has not been confirmed. Neither the occurrence of Cladonia rangiferina nor Steinia geophana or Verrucaria xyloxena has been confirmed. The former species was quoted only by Anikiejówna and Górska (1949) and the latter ones were defined by Ceynowa-Giełdon (2001) and Ceynowa-Giełdon et al. (2004) as ephemeral taxa. Historical data are related mainly to species of terricolous lichens. Previously, no detailed lichenological research has been conducted in this area and the aforementioned taxa only supplement the lists of plant species.

Furthermore, historical herbarium collections have not been preserved and therefore taxonomic verification of li- 


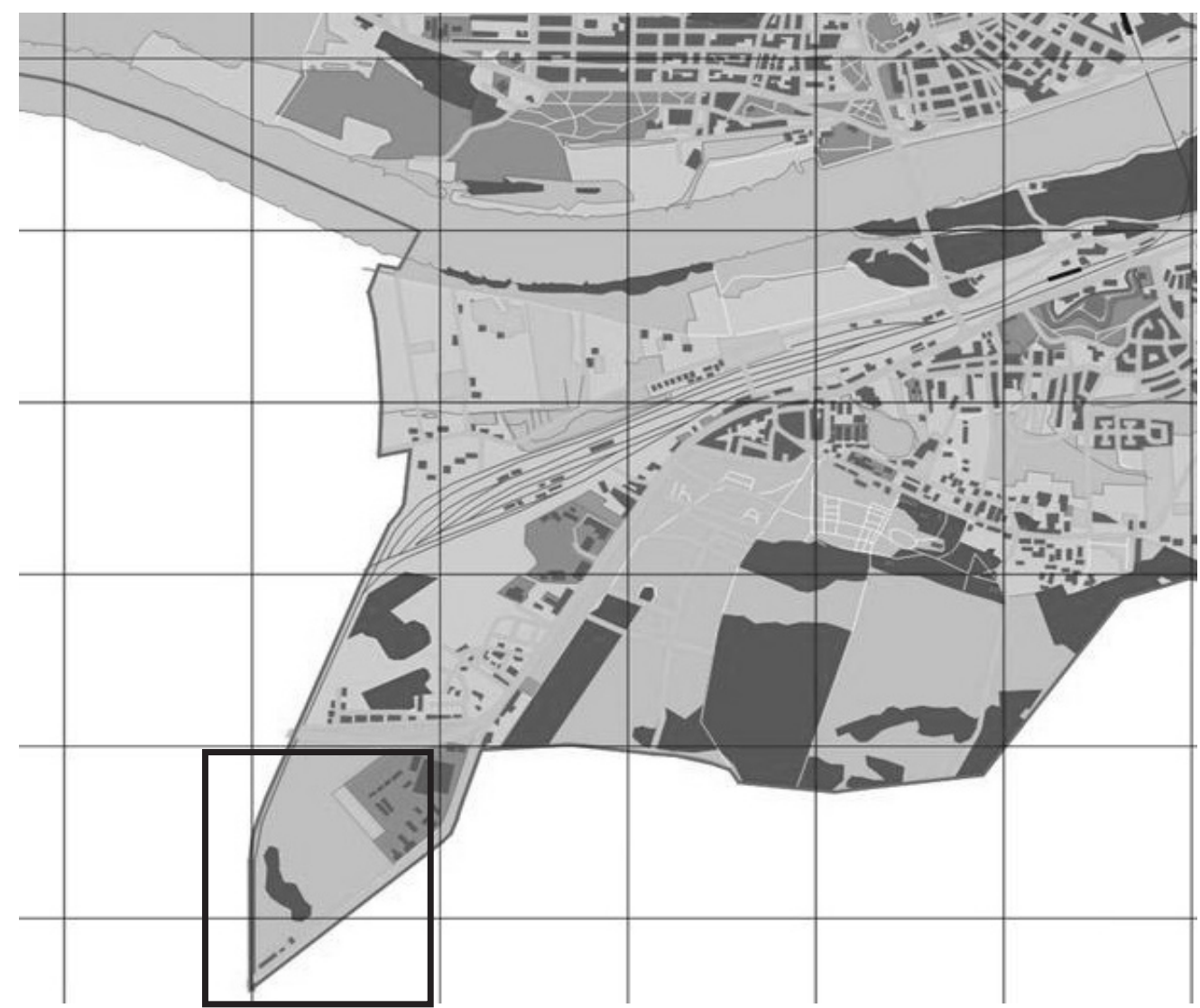

Figure 1. Fragment of the city of Torun on the left bank of the Vistula river with the indicated boundary of the study area and the grid of ATPOL squares $1 \times 1 \mathrm{~km}$ in the background

chens was impossible, particularly in the case of critical taxa.

Among 74 species recorded during my own research, taxa of terricolous lichens predominate - 29 taxa, including 20 species from the genus Cladonia. Apart from species of terricolous lichens, characteristic of acid and poor substrata, also calciphilous lichens were found in the study area. Among them e.g.: Polyblastia agraria, Peltigera canina and Cladonia furcata subsp. subrangiformis are particularly noteworthy. Those species prefer substrata enriched with calcium compounds, for instance due to dumping of concrete rubble.

Lichens populated also in large numbers the bark of Acer platanoides. 21 species of lichens were recorded on the bark of this phorophyte. Among others, the following species occurred exclusively on this substratum: Evernia prunastri, Lecanora expallens, Phlyctis argena, Pseudevernia furfuracea, Scoliciosporum sarothamni, Strangospora pinicola and Tuckermanopsis chlorophylla.
Leather of a shoe dumped on the Dune turned out to be an interesting substratum, on which 10 lichen species were recorded, including rare taxa such as: Rinodina conradii and Thelidium minutulum.

Lichens growing on thalli of other lichenized fungi from this area constitute another interesting example. And those are: Diploschistes muscorum and Scutula dedicataa rare lichenized lichenicolous fungus recorded on the thallus of Peltigera didactyla (Kukwa \& Adamska 2006).

Diploschistes muscorum is a toxitolerant and at present expansive species, also within the study area. It grows here on thalli of lichens from the genus Cladonia and on the surface of Trapeliopsis granulosa in xerothermic patches of Festuco-Koelerietum glaucae. The species is known from its capacity to accumulate substantial amounts of heavy metals, mainly $\mathrm{Zn}$ and $\mathrm{Pb}$, as well as its efficiency in their detoxification (Cuny et. al. 2004).

10 species from all lichen species recorded in the study area are listed on the Red List of lichens occurring in Poland 
Table 1. List of lichen species found in the Zadroże Dune and its neighbouring area of Torun, based on the literature and own research

\begin{tabular}{|c|c|c|c|c|c|c|c|c|c|c|c|c|c|c|}
\hline \multirow{3}{*}{ Species } & \multicolumn{3}{|c|}{$\begin{array}{l}\text { Historical } \\
\text { sources }\end{array}$} & \multicolumn{9}{|c|}{ my own data } & \multirow{3}{*}{ 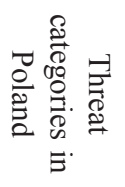 } & \multirow{3}{*}{ 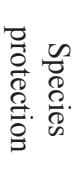 } \\
\hline & \multirow{2}{*}{$\mathrm{A}$} & \multirow{2}{*}{ B } & \multirow{2}{*}{$\mathrm{C}$} & \multicolumn{9}{|c|}{ Types of substrata } & & \\
\hline & & & & Ac & $\mathrm{Be}$ & Ps & Po & lig & ter & rup & rua & var & & \\
\hline 1 & 2 & 3 & 4 & 5 & 6 & 7 & 8 & 9 & 10 & 11 & 12 & 13 & 14 & 15 \\
\hline Acarospora fuscata (Schrad.) Th.Fr. & & & & & & & & & & + & & & & \\
\hline Buellia punctata (Hoffm.) A.Massal. & & & & + & + & & + & & & & & + & & \\
\hline $\begin{array}{l}\text { Caloplaca decipiens (Arnold) } \\
\text { Blomb.\&Forssell }\end{array}$ & & & & & & & & & & & + & & & \\
\hline Caloplaca flavocitrina (Nyl.) H.Olivier & & & & & & & & & & & + & & & \\
\hline Caloplaca saxicola (Hoffm.) Nordin & & & & & & & & & & & + & & & \\
\hline Candelaria concolor (Dicks.) Stein & & & & + & & & + & & & & & & & \\
\hline Candelariella aurella (Hoffm.) Zahlbr & & & & & & & & & & & + & & & \\
\hline Cetraria aculeata (Schreb) Fr. & + & + & + & & & & & & + & & & & & $\mathrm{pp}$ \\
\hline Cetraria ericetorum Opiz subsp. ericetorum & & + & + & & & & & & & & & & NT & $\mathrm{pp}$ \\
\hline Cetraria islandica (L.) Ach. & + & + & + & & & & & & + & & & & VU & $\mathrm{pp}$ \\
\hline $\begin{array}{l}\text { Cladonia arbuscula (Wallr.) Flot. subsp. } \\
\text { arbuscula }\end{array}$ & & & & & & & & & + & & & & & $\mathrm{pp}$ \\
\hline $\begin{array}{l}\text { Cladonia arbuscula (Wallr.) Flot. subsp. } \\
\text { mitis (Sandst.) Ruoss }\end{array}$ & + & + & + & & & & & & + & & & & & $\mathrm{pp}$ \\
\hline Cladonia cariosa (Ach.) Spreng. & & & + & & & & & & & & & & & \\
\hline Cladonia cervicornis (Ach.) Flot. & & + & + & & & & & & + & & & & & \\
\hline Cladonia chlorophaea (Sommerf.) Spreng. & & + & + & & & & & & & & & & & \\
\hline $\begin{array}{l}\text { Cladonia chlorophaea s.1. (Sommerf.) } \\
\text { Spreng. }\end{array}$ & & & & & & & & & + & & & & & \\
\hline Cladonia coniocraea (Flörke) Spreng. & & + & + & & & + & & & + & & & & & \\
\hline Cladonia cornuta (L.) Hoffm. & & + & + & & & & & + & + & & & & & \\
\hline Cladonia fimbriata (L.) Fr. & + & + & + & & & & & & + & & & + & & \\
\hline Cladonia floerkeana Fr. Flörke & & + & + & & & & & & + & & & & & \\
\hline Cladonia foliacea (Huds.) Willd. & & + & + & & & & & & + & & & & & \\
\hline $\begin{array}{l}\text { Cladonia furcata (Huds.) Schrad. subsp. } \\
\text { furcata }\end{array}$ & & + & + & & & & & & + & & & & & \\
\hline $\begin{array}{l}\text { Cladonia furcata subsp. subrangiformis } \\
\text { (Sands.) Abbayes }\end{array}$ & & + & & & & & & & & & & & & \\
\hline Cladonia glauca Flörke & & + & + & & & & & & + & & & & & \\
\hline Cladonia gracilis (L.) Willd. & + & + & + & & & & & & + & & & & & \\
\hline Cladonia macilenta Hoffm. & & + & + & & & & & + & + & & & & & \\
\hline Cladonia merochlorophaea Asahina & & & & & & & & & + & & & & & \\
\hline Cladonia phyllophora Hoffm. & & + & + & & & & & & + & & & & & \\
\hline Cladonia pleurota (Flörke) Schaer. & & & & & & & & & + & & & & & \\
\hline $\begin{array}{l}\text { Cladonia pyxidata (L.) Hoffm. subsp. } \\
\text { pyxidata }\end{array}$ & + & + & + & & & & & & + & & & & & \\
\hline Cladonia rangiferina (L.) F. H.Wigg. & + & & & & & & & & & & & & & $\mathrm{pp}$ \\
\hline
\end{tabular}




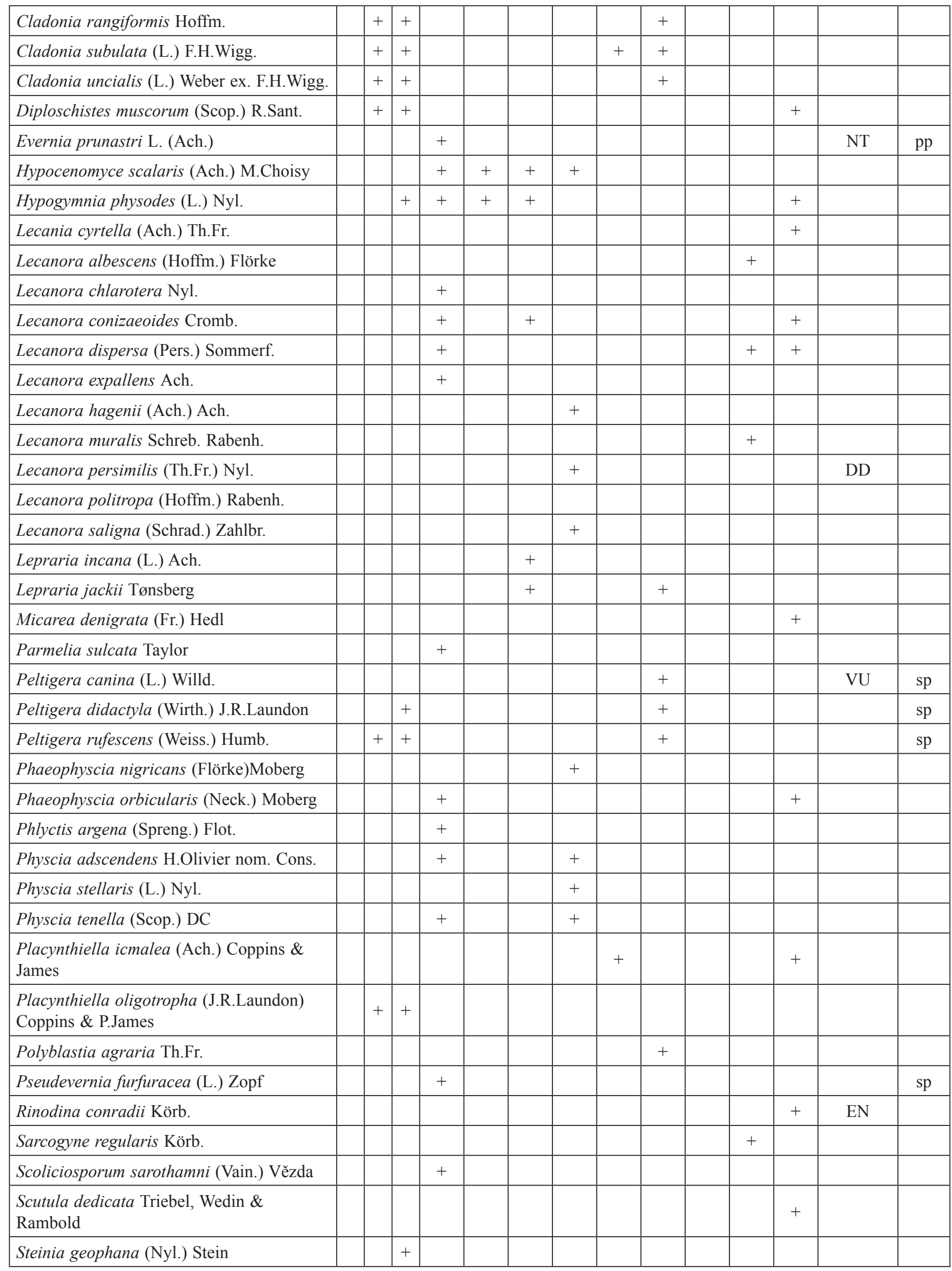




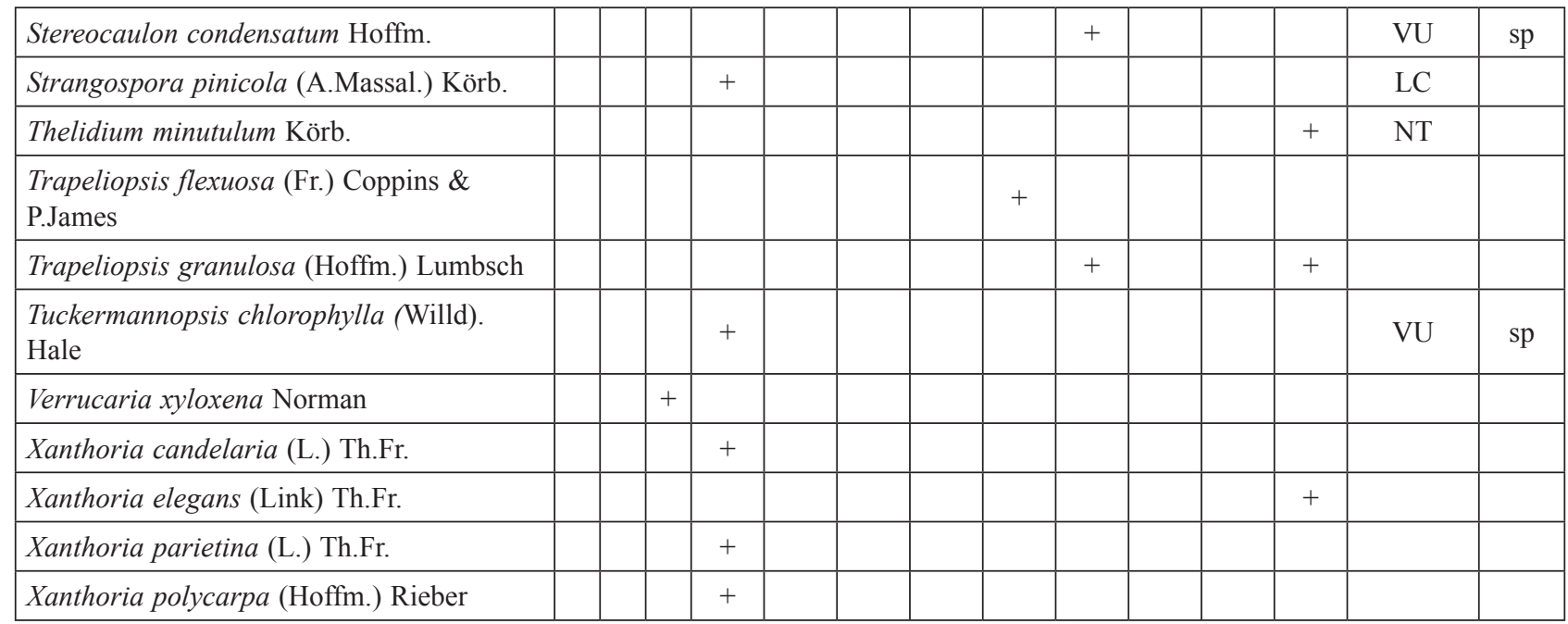

Historical date: A - according to Anikiejówna \& Gorska (1949), B - according to Ceynowa-Giełdon (1993), C- according to CeynowaGiełdon et al. (2004); substrata: Ac - Acer, Be - Betula, Ps - Pinus, Po - Populus, lig - wood, ter - soil, rup - acid bedrock, rua - calcareous substratum of anthropogenic origin, var - leather, slag, thalli of lichens; threat categories (Cieśliński et al. 2006): EN - Endangered, VU - Vulnerable, NT - Near Threatened, LC - Least Concern, DD - Data Deficient; protected by law (Rozporządzenie 2004): sp - strict protection, $\mathrm{pp}$ - partial protection

(Cieśliński et al. 2006) in 4 categories of threat, including 1 species - Rinodina conradii at the risk of extinction (EN - Endangered), 4 species exposed (VU - Vulnerable), e.g. Stereocaulon condensatum, 3 taxa NT - Near Threatened, as well as 1 species of LC - Least Concern and 1 species of unknown risk (DD - Data Deficient). Furthermore, 13 legally protected taxa were recorded here, including 6 strictly protected species (Rozporządzenie 2004).

\section{Discussion and conclusions}

In comparison with data concerning other towns of Poland, Torun turned out to be an exceptional town due to the contribution of terricolous lichens, also rare, endangered and protected ones. For instance in Poznań (Kepel 1999) and in Olsztyn (Kubiak 2005) the occurrence of 29 species of terricolous lichens from the genus Cladonia was confirmed, in Białystok Matwiejuk (2007) quoted 17 taxa, and Kiszka (1999) - only 9 species in Przemyśl.

Whereas in Torun 34 taxa from this genus were recorded in the whole town (Adamska 2008).

At present, as many as 29 species of terricolous lichens were recorded on the Zadroże Dune and its immediate surroundings, including 20 Cladonia ssp. Terricolous lichens on dry arenaceous grasslands are particularly sensitive indicators of transformations in habitat conditions, which proceed for instance as a consequence of eutrophication (Bueltmann 2005).
Long-term observations of these processes could prove that habitat conditions change within the entire ecosystem, and this should result in some actions protecting the analysed areas. On the one hand, eutrophication of the analysed habitats, particularly of dry arenaceous grasslands, constitutes a threat to species inhabiting acid, xeric and poor substrata, whereas on the other hand, it leads to spreading of nitrophilous and coniophilous species, especially epiphytic ones, such as e.g.: Phaeophyscia orbicularis or Xanthoria parietina (cf. Nash III 2008).

Similar tendencies have been observed by e.g. Kubiak (2005) in Olsztyn and Matwiejuk (2007) in Białystok, and outside Poland by e.g.: Gombert et al. (2005) in Grenoble or Munzi et. al. (2007) in Roma.

Contribution of terricolous lichens in communities of vascular plants constituted the subject of several scientific studies carried out on arenaceous grasslands (Cieśliński 1979; Czyżewska 1992).

Lichens are diagnostic of analysed associations. For example, according to Cieśliński (1979) in the association Spergulo-Corynephoretum on the Kielce-Sandomierz Upland there occur lichen species such as: Cetraria aculeata, Cladonia uncialis, Placynthiella uliginosa and Trapeliopsis granulosa, as well as species characteristic of coniferous forests - Cladonia furcata, Cetraria islandica or Cladonia glauca, what indicates certain succession connections with forest communities. The situation is similar within the Zadroże Dune in Torun. Furthermore, within the research area, also Cladonia cervicornis and C. floerkeana occur 
between patches of heather, the same way as described by Cieśliński (1979).

High nature value of the Zadroże Dune is manifested by a significant contribution of lichen species particularly sensitive to anthropopressure, included on the Red List of lichens endangered in Poland (Ciesliński et al. 2006) and provided with species protection. They make up $21 \%$ of the total number of lichen taxa recorded in the study area.

The Zadroże Dune as described by Ceynowa-Giełdon et al. (2004), due to its natural character and location within the city of Torun, attracted some interest of researchers already long time ago (Anikiejówna \& Gorska 1949).

The most significant changes in the species composition of the vegetation and lichens occurring here has been brought about by expansion of Tragopogon floccosus spreading over the dunes of the Torun Valley (CeynowaGiełdon 1993).

Another threat to biota of epigeic lichens could also be posed by the typical urban process of expansion and development of yet another areas intended for buildings and roads. Lichens of open areas lose their habitats due to afforestation, development of urbanization and secondary succession of vegetation (Czyżewska 2003).

At present, the study area is also devastated through trampling down, dumping of wastes and levelling of the area.

Due to threats posed to this naturally and historically valuable land (Tyszkiewicz 1976), it is particularly important to include the arenaceous grasslands (Namura-Ochalska 2005) and heaths (Kujawa-Pawlaczyk 2005a, b) within the framework of Natura 2000 protection.

\section{References}

Adamska E., 2008, Porosty Torunia na tle warunków siedliskowych miasta [Lichens of Torun in the habitat conditions of the city], Manuscript of the doctoral thesis, Zakład Taksonomii i Geografii Roślin Uniwersytetu Mikołaja Kopernika, Torun.

Anikiejówna Cz. \& Gorska J., 1949, Stosunki florystyczne i fitosocjologiczne wydmy Zadroże [Floristic and phytosociological relationships of the Zadroże Dune], [in:] J. Prüffer (ed.) Z badań zespołowych wydmy Zadroże [Collective investigations on the Zadroże Dune near the city of Toruń], Studia Societatis Scentiarum Torunensis, suppl. I: 27-38.

Bueltmann H., 2005, Strategies and species richness of terricolous lichens in dry sand grasslands, Tüexenia 25 425-443.

Ceynowa-Giełdon M., 1993, Rozmieszczenie i ekologia Tragopogon floccosus W. et K. s.l. w pradolinie Wisły [Distribution and ecology of Tragopogon floccosus W. et K. s. 1. in the ice-marginal valley of the Vistula
River], Acta Univ. Nicolai Copernici, Biologia XLIV Nauki Mat.-Przyr. 86: 145-164.

Ceynowa-Giełdon M., 2001, Kalcyfilne porosty naziemne na Kujawach [Calciphilous terricolous lichens in Kujawy], Wydawnictwo Uniwersytetu Mikołaja Kopernika, Torun.

Ceynowa-Giełdon M., Adamska E. \& Kamiński D., 2004, Porosty w dolinie dolnej Wisły i na obszarze przemysłowym Kujaw [Lichens in the Lower Vistula valley and in the industrial area of the Kujawy region], [in:] E. Karasińska-Korczyńska, M. Korczyński (eds.) Wycieczki geobotaniczne. Region kujawsko-pomorski, [Geobotanical excursions. The Kujawy-Pomerania Region], Bydgoszcz-Torun: 13-22.

Cieśliński S., 1979, Udział oraz rola diagnostyczna porostów naziemnych w zbiorowiskach roślin naczyniowych Wyżyny Kielecko-Sandomierskiej i jej pobrzeży [Contribution and diagnostic significance of terricolous lichens in vascular-plant communities of the KieleckoSandomierska Upland and its periphery], Wyd. Wyższa Szkoła Pedagog., Kielce.

Cieśliński S., Czyżewska K. \& Fabiszewski J., 2006, Red list of the lichens in Poland, [in:] Z. Mirek, K. Zarzycki, W. Wojewoda, Z. Szeląg (eds.), Red list of plants and fungi in Poland, W. Szafer Institute of Botany, Polish Academy of Sciences, Kraków: 71-89.

Cieśliński S. \& Fałtynowicz W., 1993, Od redakcji [Note from editors], [in:] S. Cieśliński, W. Fałtynowicz (eds.) Atlas rozmieszczenia geograficznego porostów w Polsce cz. I [Atlas of the Geographical Distribution of lichens in Poland, Part I], W. Szafer Institute of Botany, Polish Academy of Sciences, Kraków: 7-9.

Cuny D., Danayer F-O., de Foucault B., Schumacker R., Colein Ph. \& Van Haluwyn Ch., 2004, Patterns of metal soil contamination and changes in terrestrial cryptogamic communities, Environmental Pollution 129: 289-297.

Czyżewska K., 1992, Syntaksonomia śródlądowych, pionierskich muraw napiaskowych [Syntaxonomy of inland and pioneer psammnophilous grasslands], Monogr. Bot. 74: 1-174.

Czyżewska K., 2003, Wprowadzenie [Introduction], [in:] K. Czyżewska (ed.) Ocena zagrożenia bioty porostów Polski [Evolution of threat to lichens in Poland], Monogr. Bot. 91: 241-249.

Diederich P., Ertz D., Stapper N., Sérusiaux E. \& Ries C., 2009, The lichens and lichenicolous fungi of Belgium, Luxembourg and northern France, URL: http:/www. lichenology.info

Gombert S., Asta J. \& Seaward M. R. D., 2005, The use of autecological and environmental parameters for establishing the status of lichen vegetation in a baseline study for long-term monitoring survey, Environmental Pollution 135: 501-514. 
Kepel A., 1999, Porosty Poznania jako wskaźniki zanieczyszczenia atmosfery [Lichens in the city of Poznan as indicators of atmospheric pollution], Manuscript of the doctoral thesis, Zakład Taksonomii Roślin Uniwersytetu im. Adama Mickiewicza w Poznaniu, Poznań.

Kiszka J., 1999, Porosty (Lichenes) oraz warunki bioekologiczne Przemyśla [Lichens and bioecological conditions of the town of Przemyśl], Arboretum Bolestraszyce 6: $1-86$.

Kubiak D., 2005, Lichens and lichenicolous fungi of Olsztyn town (NE Poland), Acta Mycol. 40(2): 293-332.

Kujawa-Pawlaczyk J., 2005a, Ciepłolubne śródlądowe murawy napiaskowe (Koelerion glaucae) [Thermophilous inland arenaceous grasslands (Koelerion glaucae), [in:] J. Herbich (ed.) Przewodniki Ochrony siedlisk i gatunków Natura 2000 - podręcznik metodyczny. Murawy, łąki, ziołorośla, wrzosowiska, zarośla, tom 3 [Guidebooks to Protection of habitats and species Natura 2000 - a methodological textbook. Grasslands, meadows, tall herbaceous vegetation, heaths, thickets, vol. 3], Ministerstwo Środowiska, Warszawa: 80-88.

Kujawa-Pawlaczyk J., 2005b, Suche wrzosowiska (Calluno-Genistion, Pohlio-Callunion, Calluno-Arctostaphylion) [Dry heaths (Calluno-Genistion, Pohlio-Callunion, Calluno-Arctostaphylion)], [in:] J. Herbich (ed.) Przewodniki Ochrony siedlisk i gatunków Natura 2000 - podręcznik metodyczny. Murawy, łąki, ziołorośla, wrzosowiska, zarośla, tom 3 [Guidebooks to Protection of habitats and species Natura 2000 - a methodological textbook. Grasslands, meadows, tall herbaceous vegetation, heaths, thickets, vol. 3], Ministerstwo Środowiska, Warszawa: 32-48.

Kukwa M. \& Adamska E., 2006, Stanowiska dwóch interesujących grzybów naporostowych znalezionych na Peltigera ssp. w Polsce [The localities of two interesting lichenicolous fungi found on Peltigera ssp. in Poland], Fragm. Flor. Geobot. Polonica 13: 197-201.

Matwiejuk A., 2007, Porosty Białegostoku, Analiza florystyczno-ekologiczna, tom 1 [Lichens in the city of Białystok, Floristic and ecological analysis], Wyd. Ekonomia i Środowisko, Fund. Ekonomistów Środowiska i Zasobów Naturalnych, Uniwersytet w Białymstoku, Białystok.

Munzi S., Ravera S. \& Caneva G., 2007, Epiphytic lichens as indicators of environmental quality in Rome, Environmental Pollution 146: 350-358.
Namura-Ochalska A., 2005, Wydmy śródlądowe z murawami napiaskowymi [Inland dunes with arenaceous grasslands], [in:] J. Herbich (ed.), Przewodniki Ochrony siedlisk i gatunków Natura 2000 - podręcznik metodyczny. Murawy, łąki, ziołorośla, wrzosowiska, zarośla, tom 3 [Guidebooks to Protection of habitats and species Natura 2000 - a methodological textbook. Grasslands, meadows, tall herbaceous vegetation, heaths, thickets, vol. 3], Ministerstwo Środowiska, Warszawa: 191-195.

Nash III T. H., 2008, Nitrogen, its metabolism and potential contribution to ecosystems, [in:] T. H. Nash III (ed.), Lichen Biology, second edition, Cambridge Univ. Press: 216-233.

Niewiarowski W. \& Weckwerth P., 2006, Geneza i rozwój rzeźby terenu [Genesis and development of the relief], [in:] L. Andrzejewski, P. Weckwerth, Sz. Burak (eds.) Toruń i jego okolice. Monografia przyrodnicza [Toruń and its surroundings. Nature Monograph], Uniwersytet Mikołaja Kopernika w Toruniu, Toruń: 65-98.

Orange A., James P. W. \& White F. J., 2001, Microchemical methods for the identification of lichens, British Lichen Society, London.

Purvis O. W., Coppins B. J., Hawksworth D. L., James P. W. \& Moore, D. M., 1992, The lichen flora of Great Britain and Ireland, Natural History Museum \& British Lichen Society, London.

Rozporządzenie Ministra Środowiska z dnia 9 lipca 2004 r. w sprawie dziko występujących grzybów objętych ochroną. Dz. U. Nr 168, poz. 1765 [Regulation of the Minister of Environment dated July 9, 2004 on growing wild, legally protected fungi. Dz. U. (Journal of Laws) No. 168, item 1765].

Santesson R., Moberg R., Nordin A., Tönsberg T. \& Vitikainen O., 2004, Lichen-forming and lichenicolous fungi of Fennoscandia, Museum of Evolution, Uppsala University, Uppsala.

Tyszkiewicz J., 1976, Stalag XX a obóz jeńców wojennych w Toruniu w latach 1939-1945 [Stalag XX -a prisoners-of-war camp in Toruń in 1939 - 1945], Zapiski Historyczne XLI(1): 51-80.

Wirth V., 1995, Die Flechten Baden-Wurttembergs, 1-2. Eugen Ulmer, Stuttgart. 